\title{
Historical First - Professional registration for Educational Audiologists
}

\author{
Joy F Rosenberg* \\ Consultant Clinical Scientist - Audiology, Principal Lecturer and Postgraduate Programme Leader, Mary Hare partnered to University of Hertfordshire, UK
}

Submission: August 15, 2018; Published: August 22, 2018

*Corresponding author: Joy F Rosenberg, MEd, PFHEA, Consultant Clinical Scientist - Audiology, Principal Lecturer and Postgraduate Programme Leader, Mary Hare partnered to University of Hertfordshire, UK, Tel: +44 1635 244200; Email: j.rosenberg@maryhare.org.uk

\section{Opinion}

At the heart of otolaryngology and audiology professions related to children and young people who are deaf and their families is improvement in communication and consequently quality of life. Essential to these developments is a strong relationship between healthcare and education, because clinicians who have a clear understanding of life issues for children and young people who are deaf stand a much greater chance of successful clinical outcomes. To this end, the firstever professional registration for Educational Audiologists was announced by the British Association of Educational Audiologists (BAEA) in Jun 2018. The voluntary registration is with the United Kingdom's Registration Council for Clinical Physiologists (RCCP) who enforce high standards of practice and maintain a public database of registrants for six disciplines. It was facilitated by innovative teamwork to improve quality of service in local areas across Britain, including development of a new memorandum of agreement with the British Academy of Audiology [1-4].

BAEA are extremely pleased to make this announcement because of the benefits for children and young people who are deaf and their families. Professional registration will improve joined-up working between Health and Education and promote public recognition of the need for these links and the educational audiology role that fulfils it in many authorities. These issues have been evidenced empirically (2017 BATOD* conference presentation cited in 2017 Department for Education Future of the Sector report) and anecdotally (BAEA case studies, and MESH $^{* *}$ knowledge management Guides); and have featured internationally at the Hearing Across the Lifespan conference 2018 and in an upcoming British Society of Audiology's CPD e-module. Professional registration is timely news because of the threat of budget cuts to essential support services most often provided by the nonmandatory Educational Audiology role [57].
Since the 1990's, Educational Audiologists in the United Kingdom have been trained at Mary Hare (https://www.maryhare.org. uk/professional-courses/postgraduate-courses). Now affiliated with University of Hertfordshire. This MSc/PGDip course, based on BAEA competencies, has now been accredited by the RCCP supported by the British Academy of Audiology (BAA), which opened the way for registration. New graduates of the course will be automatically eligible to register, and others can apply via an equivalency process. Efforts begun with the 1970's Education Act and fostered by several leaders in the field since then have now come to fruition [9-10].

\section{References}

1. http://www.educational-audiologists.org.uk/index.php

2. https://www.rccp.co.uk/

3. https://www.maryhare.org.uk/professional-courses/postgraduatecourses

4. https://www.herts.ac.uk/apply/schools-of-study/education/ partnerships-in-education/uk-education-partners

5. http://www.baaudiology.org/

6. http://www.thebsa.org.uk/

7. https://www.batod.org.uk/about-us/

8. *https://www.natsip.org.uk/doc-library-login/natsip-briefingdocuments-and-papers/future-of-the-sector-report/1270future-of-the-sector-report?highlight $=$ WyJmdXR1 cmUiLCJm dXR1cmUnIiwib2YiLCJ0aGUiLCIndGhlIiwic2VjdG9yIiwiZnV 0 dXJIIG 9 mIiwiZnV0 dXJIIG 9 mIHRoZSIsIm9 mIHRoZSIsIm9m IHRoZSBzZWN0b3IiLCJ0aGUgc2VjdG9yll0

9. http://www.heal2018.org/

10.**http://www.meshguides.org/category/meshguides-published/ special-needs-send/deaf-education/ 
(C) (i) This work is licensed under Creative BOI: 10.19080/GJO.2018.17.555958
Your next submission with Juniper Publishers will reach you the below assets

- Quality Editorial service

- Swift Peer Review

- Reprints availability

- E-prints Service

- Manuscript Podcast for convenient understanding

- Global attainment for your research

- Manuscript accessibility in different formats

( Pdf, E-pub, Full Text, Audio)

- Unceasing customer service

Track the below URL for one-step submission https://juniperpublishers.com/online-submission.php 